\title{
RECENT DEVELOPMENT
}

\section{CATTLEMEN'S INVESTMENT CO. v. FEARS: INFORMAL SOLICITATION OF STOCK HELD TO CONSTITUTE A TENDER OFFER}

In Cattlemen's Investment Co. v. Fears, ${ }^{1}$ the District Court for the Western District of Oklahoma construed the term "tender offer" of section 14(d) of the Securities Exchange Act of 1934, as amended by the Williams Act of $1968,{ }^{2}$ to include the direct solicitation of shares from a corporation's shareholders through utilization of the mails, telephone calls and personal visits, whereby the offeror acquired ownership of more than five percent of the company's outstanding stock. ${ }^{3}$ During November and early December of 1971, the defendant obtained either a legal or beneficial interest in a sufficient number of shares of Cattlemen's Investment Company to increase his total holdings in the stock from 4.86 percent to approximately twelve percent. ${ }^{4}$ The total stock acquired by the defendant therefore exceeded the five percent reporting limit fixed by section 14(d) which requires the offeror of a tender offer to file specified background information and statements of intent with the Securities and Exchange Commission (SEC) and to disclose prescribed information to the target corporation prior to making an offer to shareholders to purchase their holdings of the target company's stock. ${ }^{5}$ The defendant admitted that he had failed to comply with the requirements of section 14(d) but argued, in part, that his actions did not, as a matter of law, constitute tender offers. ${ }^{6}$ Determining that section 14 (d) reflects a congressional intent to regulate the solicitation activities involved in the instant case, ${ }^{7}$ the court issued a temporary restraining order enjoining the defendant from voting any stock of the plaintiffcorporation acquired during the period in question. ${ }^{8}$

During the mid-1960's, the incidence of cash tender offers by

1. 343 F. Supp. 1248 (W.D. Okla. 1972).

2. 15 U.S.C. $\S 78 \mathrm{n}(\mathrm{d})(1970)$.

3. 343 F. Supp. at 1252 .

4. Id. at 1250 .

5. See note 17 infra and accompanying text.

6. 343 F. Supp. at $1250,1252$.

7. Id. at $1251-52$.

8. Id. at 1253 . 
outsiders for the purpose of gaining control of publicly held corporations increased dramatically. ${ }^{9}$ Since no reporting or disclosure requirements with respect to tender offers were prescribed in the 1934 Act, ${ }^{10}$ the managements of numerous large corporations were abruptly displaced in circumstances where the insiders had virtually no opportunity to counter the "raiders" " offers." In view of this development, Senator Williams of New Jersey introduced legislation for the purpose of protecting incumbent management from what were deemed to be reckless corporate raids. ${ }^{12}$ While this proposal died in

9. See generally Brown, The Scope of the Williams Act and Its 1970 Amendments, 26 Bus. LAw. 1637 (1971); Brudney, A Note on Chilling Tender Solicitations, 21 RuTgERs L. REv. 609 (1967); Fleischer \& Mundheim, Corporate Acquisition by Tender Offer, 115 U. PA. L. Rev. 317 (1967); Griffin \& Tucker, The Williams Act, Public Law 90-439_Growing Pains? Some Interpretations with Respect to the Williams Act, 16 How. L.J. 654 (1971); Hamilton, Some Reflections on Cash Tender Offer Legislation, 15 N.Y.L.F. 269 (1969); Kennedy, Tender Moment, 23 Bus. LAw. 1091 (1968); O'Boyle, Changing Tactics in Tender Offers, 25 Bus. LAW. 863 (1970); Young, Judicial Enforcentent of the Williams Amendments: The Need to Separate the Questions of Violation and Relief, 27 Bus. LAw. 391 (1972); Note, Cash Tender Offers, 83 HaRv. L. Rev. 377 (1969); Note, Defensive Tactics Employed by licumbemt Managements in Contesting Tender Offers, 21 StaN. L. REv. 1104 (1969).

The basic outline of a cash tender offer has been described in Griffin \& Tucker, supra. The authors state:

When the proposed take-over of a corporation is structurcd as a cash tender offer the bidder requests, invites, or solicits tenders of shares of the target issuer in rcturn for a cash payment at a premium above the market price. In some instances the bidder individually, or in conjunction with others, accumulates shares of the target issuer in the market or through privately negotiated transactions. $1 d$. at 657.

For a description of the fundamental characteristics of target corporations and "aggressor" corporations, see Cohen, Tender Offers and Takeover Bids, 23 Bus. LAw. 611 (1968).

10. Securities Exchange Act of $1934 \S 14$, ch. 404, $\S 14,48$ Stat. 895 (1934), as amended, 15 U.S.C. $\$ 78 \mathrm{~m}(\mathrm{~d})-(\mathrm{e}), 78 \mathrm{n}(\mathrm{d})$ - (e) (1970).

11. See note 9 supra. Senator Kuchel of California, co-sponsor of the Williams Act, cited the example of Columbia Motion Pictures as a particularly flagrant example of a take-over bid. A Swiss branch of a French bank representing an unknown number of individuais inade a tender offer to purchase a large amount of Columbia stock. In fact, the bank purchascd approximately 675,000 shares, or thirty-four percent of the stock, which was then assigned largely to two American mutual funds. Together with the bank, the mutual funds attempted to gain control of the corporation without the incumbent management's having had an opportunity to counter the offer. Senator Kuchel contended that because of the possibility of forcign take-overs, a grave question of national interest was involved in such transactions. 113 CoNG. REC. 858-59 (1967).

I2. II I CONG. REC. $28,257-60$ (I965). The original proposal presented by Senator Williams in 1965 was clearly hostile to attempted take-over bids and was designed to protect incumbent managements from "corporate raiders." In introducing the bill, Senator Williams stated:

In recent years we have seen proud old companies reduced to corporate shells after white-collar pirates have seized control with funds from sources which are unknown in many cases, then sold or traded away the best assets, later to split up most of the loot among themselves. Id. at 28,257.

The original bill required the notification of the target corporation and the filing of a public 
the 89th Congress, the SEC indicated its general concurrence with the objectives of the bill and recommended extensive alterations which were thereafter incorporated into a bill introduced in 1967 and passed by Congress in $1968 . .^{13}$ Based upon the premise that investor confidence in the securities market can be achieved only when all transactions are conducted pursuant to full disclosure of material information, the proposed legislation was designed to fill a gap in the existing scheme of reporting requirements. ${ }^{14}$ Although Congress intended to protect shareholders in target corporations by enacting certain reporting requirements, the measure reflected a congressional desire to promote investor protection ${ }^{15}$ without unduly impeding cash takeover bids. ${ }^{16}$

As enacted in 1968, the Williams Act renders unlawful activities whereby any person utilizes the mails or any means of interstate commerce "or otherwise" to acquire, by means of a tender offer, more than ten percent (amended to five percent in 1971) of the shares of a company's equity securities without first filing certain prescribed

statement with the SEC containing essential information at least twenty days before the making of any cash tender offer which would result in the acquisition of, or would increase the ownership of the offeror to, more than five percent of a class of security registered under the Act. The bill covered acquisitions by any other means than a tender offer where the five percent limit would have been exceeded.

13. S. 510 was later enacted as Act of July 29, 1968, Pub. L. No. 90-439, 82 Stat. 454 (1968), amending 15 U.S.C. $\$ 78 \mathrm{~m}-\mathrm{n}$ (1964) (codified at 15 U.S.C. $\$ 78 \mathrm{~m}(\mathrm{~d})-(\mathrm{e}), 78 \mathrm{n}(\mathrm{d})-$ (I) (1970)). See 113 ConG. Rec. 854 (1967). See also S. Rep. 550, 90th Cong., 1st Sess. 3-4 (1967): 113 CONG. REC. 24,662-66 (1967).

14. See, e.g., H.R. REP. No. 1711, 90th Cong., 2 d Sess. 10 (1968); S. REP. No. 550, supra note 13 , at 4 .

15. The extent to which the co-sponsors of the bill, Senators Williams and Kuchel, intended that the focus of S. 510 be changed from that of the bill that died in the 89th Congress is open to question. During the hearings before the Senate Business and Finance Committce, Senator Kuchel uscd language almost identical to that employed by Senator Williams when he introduced the bill in 1965, when the focus was clearly upon the protection of incumbent management. After Senator Kuchel's testimony on S. 510, Senator Williams commented that Senator Kuchel had aptly expressed the sentiments of the entire committee. Compare Hearings on $S$. 510 Before the Subcomm. on Securities of Senate Comm. on Banking and Currency, 90th Cong., Ist Sess. 42 (1967) with 113 CoNG. REC. 854 (1967) and id. 24,662-66.

16. 113 CONG. ReC. 854 (1967). See S. ReP. No. 550, supra note 13, at 3-4.

it has been forcefully argued that take-over bids in the form of cash tender offers often serve useful economic purposes:

[T]ake-over bids apparently tend to be made predominantly in circumstances in which incumbent management or controllers have not distinguished themselves by the success of their conduct of corporate business. The evidence indicates that acquisition attempts have been made primarily with respect to corporations with lower rates of return or net worth than comparable enterprises, and with histories of fluctuating or declining earnings and dividends . . . Moreover, the number of take-over bids made 
information with the SEC. ${ }^{17}$ Notwithstanding this general rule, the statute exempts certain transactions from regulation. Tender offers made through a registration statement under the 1934 Act, ${ }^{18}$ acquisitions during the previous twelve months constituting not more than two percent of the same class of target securities, ${ }^{19}$ and offers made by the issuer for its own securities are expressly excepted from the purview of the statute. ${ }^{20}$ In addition to these specific exemptions, the statute also provides that the SEC may properly elect not to regulate certain offers which are "not entered into for the purpose of, and not having the effect of, changing or influencing the control of the issuer "21

by persons intending to loot, or even to liquidate or dismantle, the enterprise appears to be relatively small when compared with the number of take-over bids designed to serve more respectable or legitimate purposes, however arguable may be their economic merits. The evidence plainly does not justify impeding all the latter bids in order to deter the former. Brudney, supra note 9, at 627.

An excellent analysis of the economic aspects of cash take-over bids is contained in Fleischer \& Mundheim, supra note 9, and in Hayes \& Taussig, Tactics of Cash Take-Over Bids, 45 Harv. Bus. Rev., Mareh-April 1967, at 135, 138.

17. The original ten percent requirement was changed to five percent by Act of Dec. 22 , 1970, Pub. L. No. 91-567, § 3(2), 84 Stat. 1497, amending 15 U.S.C. $\$ 78 n(d)(1)$ (1964). 15 U.S.C. $\S 78 \mathrm{n}(\mathrm{d})(1)(1970)$ presently provides:

It shall be unlawful for any person, directly or indirectly, by use of the mails or by any means or instrumentality of interstate commeree or of any facility of a national securities exchange or otherwise; to make a tender offer for, or a request or invitation for tenders of, any class of any equity security which is registered pursuant to section 78l of this title, or any equity security of an insurance company which would have bcen required to be so registered except for the exemption contained in section $78 /(\mathrm{g})(2)(\mathrm{G})$ of this title, or any equity security issued by a closed-end investment company registered under the Investment Company Act of 1940, if, after consummation thereof, such person would, directly or indirectly, be the beneficial owner of more than 5 per centum of such class, unless at the time copies of the offer or request or invitation are first publishcd or sent or given to security holders such person has filed with the Commission a statement containing such of the information specified in section $78 \mathrm{~m}(\mathrm{~d})$ of this title, and such additional information as the Commission may by rules and regulations prescribe as necessary or appropriate in the public interest or for the protection of investors . . . .

The statute indicates the information which must be reported when a cash tender offer is made within the ambit of section 14(d): (1) the background and identity of the pcrson or group on whose behalf the offer is being made; (2) the source and amount of funds available to the person or group; (3) if the purpose of the merger is to take control, plans for liquidation, merger, or major changes must be indicated; (4) the size of the holdings of the person or group involved; (5) any contracts or arrangements already made relating to the shares. Id. $\S 78 \mathrm{~m}(\mathrm{~d})(1)(1970)$

18. 15 U.S.C. $\S 78 n(d)(8)(1970)$.

19. $I d . \S 78 \mathrm{n}(\mathrm{d})(8)(\mathrm{A})$.

20. $I d . \S 78 \mathrm{n}(\mathrm{d})(8)(\mathrm{B})$.

21. $I d . \S 78 \mathrm{n}(\mathrm{d})(8)(\mathrm{C})$.

Congress granted broad rulemaking authority under the statute to the SEC whereby the 
Although the Williams Act was designed to regulate take-over attempts, the statute does not specifically define the parameters of "tender offer"- a primary method of achieving corporate control. As normally used, "tender offer" connotes the public advertisement of an offer to purchase, within a certain period of time, a quantity of an equity security for a specified price above the prevailing market rate. ${ }^{22}$ However, in view of statutory silence with respect to the meaning of the term, as well as the failure of the SEC through its regulatory powers to clarify the issue, resort must be made to both the legislative history of the measure and to SEC-promulgated regulations for guidance in reaching the appropriate understanding of the term. With respect to congressional intent, three paramount legislative concerns which bear upon the type of economic activity sought to be regulated are reflected in the statute. First, Congress desired to provide investors holding an equity interest in a public corporation with the information necessary to evaluate the potential impact of a possible takeover. ${ }^{23}$ Second, a need was discerned to provide sufficient time for shareholders to make a prudent investment decision when confronted with an offer to purchase securities. ${ }^{24}$ Finally, the legislation was deemed vital in order to insure equitable treatment of investors. ${ }^{25}$ In addition to these broad legislative purposes, which suggest an expansive understanding of "tender offer," the Senate and House Reports clearly manifest an even broader congressional intent to impose filing and disclosure obligations upon all persons or groups attempting to acquire control of a corporation, regardless of whether

Commission would be enabled to distinguish for regulatory purposes between purely investment acquisitions and acquisitions for control. By means of these rulemaking powers, the SEC has periodically included other investor activities under the shield provided for shareholders by the Williams Act. For example, the Commission has held that even an order to purchase equity securities through a national securities exchange, which, if consummated, would increase the buyer's total holdings to over five percent, constitutes a tender offer under section 14(d). SEC Exchange Act Release No. 8392 (Aug. 30, 1968), reprinted in [1969-1970 Transfer Binder] CCH FED. SEC. L. REP. I 77,715 (1969).

22. Two securities lawyers recently published an article outlining the more traditional concepts of a tender offer, as understood in the business community, which the writers think would be covered by the Williams Act:

. . . a public offer or solicitation by a company, an individual or a group of persons to purchase during a fixed period of time all or a portion of a class or classes of securities of a publicly held corporation at a specified price or upon specified terms for cash and/or securities. Aranow \& Einhorn, Essential Ingredients of the Cash Tender Invitation, 27 Bus. Law. 415 (1972).

23. H.R. REP. No. 17II, supra note 14 , at 3-4; S. REP. No. 550 , supra note 13 , at $2-3$.

24. Id.

25. Id. 
the method utilized is proxy solicitation, a registered exchange offer of securities, or a cash tender offer ${ }^{26}$ Taking advantage of the congressional failure to provide specific statutory guidelines in this area, the SEC has not restricted the ambit of its regulatory concern by attempting to define "tender offer." 27 The failure to delineate the

26. The first indication of congressional intent underlying the enactment of the Williams Act was voiced by Senator Williams when he first introdueed legislation to control tender offers in 1965:

The legislation I propose as an amendment to Securities Exchange Act of 1934 would provide that any cash tender offers and, indeed, any substantial accumulation of shares of a company registered under that aet be preceded by the filing of public information that provides answers to all of these questions. 111 CoNG. REC. 28,259 (1965) (emphasis added).

A sketch of the type of financial maneuvers which the Williams Act was designed to remedy was presented at the Senate hearings in 1967.

By using a cash tender offer the person seeking control can operate in almost complete secrecy. He need not state the source of his funds; who his associates are; why he wants to acquire control of the corporation; and what he intends to do with it if he gains control. Unless incumbent management takes newspaper ads explaining its position, the investor has no facts before him on which to base a decision as to whether or not he should accept the offer. Hearings on S. 510, supra note 15, at 2.

The basic purpose which the Act was designed to effectuate, as expressed in the House hearings, was not "to prevent the making of any such offers, but solely the purpose of seeing that investors adequately are informed of the relative merits of their position before and after accepting such offers so that they can make a judgment properly required." Hearings on H.R. 14475 Before the Subcomm. on Commerce and Finance of the House Comm. on Interstate and Foreign Conmerce, 90th Cong., 2d Sess. 1 (1968).

Perhaps the most inclusive statement of the intent behind the Williams Act was voiced at the 1967 Senate debates:

The bill amends the Securities Exchange Act of 1934 to require the disclosure of pertinent information, first, when a person or group of persons seek to acquire a substuntial block of equity securities of a corporation by a cash tender offer or through the open market or privately negotiated purehases, and second, when a corporation repurehases its own equity securities. 113 CoNG. REc. 24,664 (1967) (remarks of Senator Williams).

Based on the assumption that secrecy has no place in the securities market where publie confidence is vital, Chairman Cohen of the SEC indicated, both before and during the liearings, his desire for uniform reporting requirements, regardless of the method utilized in obtaining substantial amounts of equity securities:

If we are to retain and build investors' confidence in the integrity of our securities markets, so vital to the free flow and development of capital in our country, we must place all participants in the seeurities markets in a position to compete on an equal footing with respect to the availability of significant facts about a company, its management and its securities. This is the premise on which our securities markets are supposed to work, and all Americans, whether shareholders or not, have a vital stake in making sure that it is a correct one. Cohen, $A$ Note on Take-Over Bids and Corporate Purchases of Stock, 22 Bus. LAw. 149, 157 (1966).

27. See Brief for SEC as Amicus Curiae at 9, Cattlemen's Inv. Co. v. Fears, 343 F. Supp. 1248 (W.D. Okla. 1972):

[T]he Commission has not restricted itself by adopting a definition of the term tender offer, but has instead chosen to excise by rule certain limited types of transactions whieh would otherwise fall within the terminology in question. 
meaning of the term can reasonably be viewed as indicative of an SEC preference for the present ambiguity of the statute as a vehicle for regulating varied types of conduct tending to effect corporate control. ${ }^{28}$

In Cattlemen's Investment Co. v. Fears, ${ }^{29}$ the plaintiff alleged that the defendant had violated the 1934 Act, as amended by the Williams Act, by virtue of his active campaign to acquire shares of the plaintiffcorporation in excess of five percent, without complying with the registration and notification requirements established by section 14(d). ${ }^{30}$ In addition to interposing several threshold defenses, including an argument attacking the propriety of the plaintiff's maintaining the action, ${ }^{31}$ the defendant urged that his actions were not within the purview of the 1934 Act and, more specifically, were outside the meaning of the term "tender offer" as employed by Congress. ${ }^{32}$ In rejecting the defendant's arguments, the court postulated that, since the Williams Act was intended to serve as a remedial statute, the measure should be interpreted liberally to effectuate legislative purposes. ${ }^{33}$ Accordingly, the court accepted the proposition that the target company itself has standing to sue the tender offeror for viola-

28. See Note, 83 Harv. L. Rev., supra note 9, at 388. Despite its previous failure to formulate a definition, the SEC, in its amicus brief in the instant case, contended that the legislation "must be read expansively and not be restricted to the traditional form of an advertisement of a general offer to shareholders." Brief for SEC, supra note 27 , at 8.

29. 343 F. Supp. 1248 (W.D. Okla. 1972).

30. Brief for Plaintiff at 2, Cattlemen's Inv. Co. v. Fears, 343 F. Supp. 1248 (W.D. Okla. 1972).

31. These defenses were premised upon the contention that the plaintiff-corporation did not have standing to sue inasmuch as the statute was designed to benefit shareholders, not management. Brief for Defendant at 3-6, Cattlemen's Inv. Co. v. Fears, 343 F. Supp. 1248 (W.D. Okla. 1972).

32. Id. at 11-12. In examining the remarks by Senator Williams, set forth in note 12 supra, as utilized by the plaintiff in its brief, the defendant relied on assertions of grammatical construction in presenting his argument:

It is obvious that any definition which contains the term to be defined [tender offer] is useless; and it is equally obvious through the use of the disjunctive "or" that Senator Williams considered both "privately negotiated purchases" and purchases made "through the open market" as different from a "tender offer." If anything, the instant case would appear to involve "privately negotiated purchases." Id. at 11 .

The defendant then turned to a more valid area of inquiry by challenging the definition and usage of the term "tender offer" according to traditional concepts of the term: "a general offer to shareholders by means of wide publicity to all known shareholders." Id.

33. 343 F. Supp. at 1251 . For prior support of this approach, the court relied upon Tcherepnin v. Knight, 389 U.S. 332, 336 (1967) and Marriott v. National Mut. Gas Co., 195 F.2d 462, 466 (10th Cir. 1952). 
tions of the statute. ${ }^{34}$ After determining that the plaintiffcorporation could properly maintain an action under the Williams Act, the court examined the scope of "tender offer" by resort to the provision's legislative history. In its analysis the court discerned a congressional desire to provide stockholders in public-issue corporations with "material information with respect to the potential impact of any effort to acquire control of a company .. ." so that an adequate opportunity for making a prudent investment decision would exist. ${ }^{35}$ Closely paralleling the interpretations of "tender offer" proffered by the SEC in its amicus curiae brief ${ }^{36}$ and by the plaintiff, ${ }^{37}$ the court concluded that:

the activities of the defendant in making contact with plaintiffs shareholders by use of the mails, telephone calls, and personal visits, for the purpose of purchasing their shares, constitute "tender offers for, or a request or invitation for tender offers of" their stock within the meaning of the statute. ${ }^{38}$

According to the court, both the corporation and the shareholders had been deprived of information upon which an intelligent investment decision could be based. ${ }^{39}$ Therefore, the court enjoined the defendant from voting his newly acquired shares until after a trial of the action on the merits. ${ }^{40}$

34. In determining that the corporation had standing to sue for injunctive relief, the court relied upon the Second Circuit's decision in Electronics Specialty Co. v. International Controls Corp., 409 F.2d 937 (2d Cir. 1969). In that case, the court had held that, in view of the most appropriate manner to accomplish the purposes of the Williams Act, a target corporation has standing to complain of an offeror's violation of the Act.

As to the propriety of granting injunctive relief in the instant case, the court indicated that corporate "rigor mortis" was not a requisite to such relief. Indeed, the court concluded that in requesting injunctive relief, the plaintiff need only demonstrate that there would otherwise be a sufficiently adverse effect that the resulting harm would be irreparable. See United Egg Producers v. Bauer Int'I Corp., 31 I F. Supp. 1375 (S.D.N.Y. 1970).

35.. 343 F. Supp. at 1251 (emphasis added).

36. Brief for SEC, supra note 27 , at 7.

37. Brief for Plaintiff, supra note 30, at 4-6.

38. 343 F. Supp. at 1252.

39. Id. at I253. The court's analysis with respect to the corporation's need for the prescribed information is unclear. Although the court indicates that the information is necessary for making "investment decisions," $i d$., there was no allegation that the corporation itself was a shareholder, nor that the defendant had made an offer to purchase to the corporation in the latter's capacity as a shareholder.

40. The plaintiff also sought to enjoin the defendant for a period of five years from acquiring additional shares and from exercising any voting rights of the shares owned by him, thereby including the voting rights of those shares properly acquired at an earlier time. Significantly, the court enjoined the exercise of voting rights only as to the stock obtained in violation of the statute. Id. 
Cattlemen's represents an exercise in proper judicial craftsmanship inasmuch as the court construed a legislatively undefined term to accurately reflect underlying congressional intent, notwithstanding a more limited, common understanding of that concept. Despite the defensible viewpoint that, by failure to specify to the contrary, Congress employed "tender offer" in its normal sense, an examination of the hearings and reports relating to the Williams Act indicates that the co-sponsors of the measure intended a much broader construction of the statutory terms than the interpretation used by the segment of the business community at which the legislation was directed. Senators Williams and Kuchel had indicated that their primary concern was the creation of a protective shield for management from any sort of surprise take-over bid by outsiders. ${ }^{41}$ In short, the broad language used in the reports issued by the Senate and House Committees in defining the purpose and design of the bill, coupled with the broad rule-making authority accorded the SEC by the Act, ${ }^{42}$ leaves little doubt that the intent of Congress was supportive of a generous reading of "tender offer." It is also apparent that, since the measure's enactment, the SEC has sought to insure widespread compliance with the reporting requirements of the statute by failing to delimit specifically the scope of a tender offer through definition or regulation. The Commission has sought to encompass all varieties of activity designed as take-over bids within the scope of its regulatory powers. Such vagueness in legislative terminology, ${ }^{43}$ as well as the tactics employed by the SEC, was likely to result in considerable confusion with respect to the meaning of "tender offer." Therefore, it is not surprising that the defendant in the instant case, when charged with a violation of section 14(d) due to his acquisition of stock by means of direct personal contacts with shareholders, as opposed to the medium of public advertisement, raised the defense of not having extended a "tender offer" as the term is generally defined. Nevertheless, in view of the remedial nature of the legislation, the liberal readings traditionally accorded such acts by the courts, ${ }^{44}$ and the obvious legislative intent behind the Williams Act, it seems clear that the court in

41. It should again be noted that the co-sponsors' acquiescence in the SEC-sponsored change in emphasis to the protection of shareholders was seemingly superficial so far as their broad intentions were concerned. See note I5 supra.

42. See notes $17 \& 21$ supra and accompanying text.

43. The entire Act speaks in terms of ". . . copies of the offer or request or invitation . . [being] published or sent or given to sccurity holders." 15 U.S.C. $\S 78 \mathrm{n}(\mathrm{d})(\mathrm{I})$ (I970).

44. See note 33 supra and accompanying text. 
Cattlemen's properly construed the statute. As to legislative draftsmanship, however, the wisdom of leaving completely to the courts the task of defining a highly fundamental term when the potential for conflict in the federal courts is quite substantial can be seriously questioned. Moreover, prior to the Cattlemen's decision, reluctance in the business community to employ the cash tender offer as an economic tool resulting from both legislative vagueness and potential judicial conflict could have operated to limit the beneficial aspects of cash tender offers-a result which Congress explicitly intended to avoid. In sum, the Cattlemen's decision not only embodies an appropriate statutory construction but, in addition, ameliorates the probable adverse business consequences flowing from previous confusion as to the reach of federal regulation of take-over bids. 